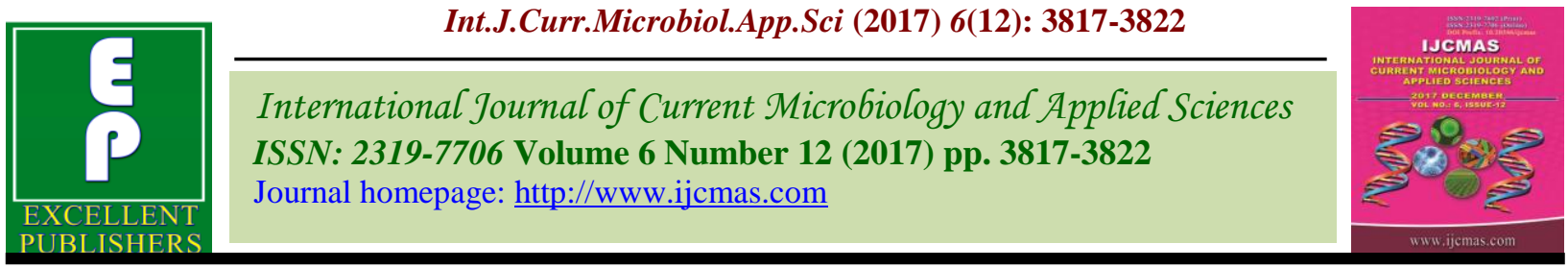

Original Research Article

https://doi.org/10.20546/ijcmas.2017.612.439

\title{
Factors Influencing in Ajwain Cultivation in Chittorgarh District of Rajasthan, India
}

\author{
M. Kanwat ${ }^{1 *}$, N.R. Meena ${ }^{2}$ and N.K. Meena ${ }^{3}$ \\ ${ }^{1}$ KVK Anjaw, ICAR RC for NEH Region, ICAR AP Centre, Basar, Arunachal Pradesh, India \\ ${ }^{2}$ L.M.C.L Agriculture College of Agriculture, Lalsot, Dusa, Rajasthan, India \\ ${ }^{3}$ College of Post Graduate Studies, CAU (I), Umiam, Meghalaya, India \\ *Corresponding author
}

\begin{tabular}{|l|}
\hline K e y w o r d s \\
Factor analysis, \\
$\begin{array}{l}\text { Ajwain, Constraint, } \\
\text { Chittorgarh, } \\
\text { Rajasthan, India. }\end{array}$ \\
\hline Article Info \\
\hline $\begin{array}{l}\text { Accepted: } \\
\text { 28 October } 2017 \\
\text { Available Online: } \\
10 \text { December } 2017\end{array}$ \\
\hline
\end{tabular}

Keywords

Factor analysis, Ajwain, Constraint,

Chittorgarh,

Rajasthan, India

Accepted:

10 December 2017

\section{A B S T R A C T}

There has not taken any major step for mass cultivation of medicinal plants. In this context, review of factors affecting the cultivation of Ajwain is very important. This study has also been accomplished for the purpose of identification of factors affecting the cultivation of Ajwain in Chittorgarh district of Rajasthan, India. A survey was conducted using a stratified random sampling to collect data from farmers of selected rural in Nimbahera and Chhoti Sadri panchayatsamities of Chhitorgarh district. The questionnaire validity and reliability were also determined to enhance the dependability of the result. The present study was undertaken with the objectives to study the constraints perceived the farmers in cultivation of Ajwain crop in Chittorgarh district of Rajasthan. A total number of respondents are selected by simple random sampling techniques. In this way 80 farmers were studied from eight villages of two panchayatsamities of Chittorgarh district (10 farmers from each village). The data were collected from each respondent through personal interview methods with the help of structured schedule. It was observed that technological constraints were most important as it was ranked in $1^{\text {st }}$ position. This was followed by marketing, financial and storage constraints which were accorded II, III and IV ranks order by the respondents.

\section{Introduction}

The medicinal plants, sector at present are not well organized and needs special attention. Medicinal plants market in the country is today unorganized due to several problems, medicinal plants are a living resource, exhaustible if over used and sustainable if used with care and wisdom. At present 95 per cent collection of medicinal plants is from the wild. The current practices of harvesting are unsustainable and many studies have highlighted the depletion of the resources bases. Many studies have confirmed that pharmaceutical companies are also responsible for inefficient imperfect, informal and opportunistic marketing of medicinal plants. There is a vast, secretive and largely unregulated trade in medicinal plants, mainly from the wild, which continues to grow in the absence of serious policy attention with environmental planning.

Thanks to India's potentials and an increasing demand for medicinal plants in the global as well as domestic market. Looking to the 
biodiversity and favorable environment, India's present export share is not encouraging. Presently commercial cultivation of medicinal plants in India is restricted to few crops like Plantagoovata (Isabgol), Trachyspermum copticum (Ajwain), Withania somnifera (Ashwaganda), Papaver somniferum (Opium poppy), Cassia angustifolia (Senna) etc.

Marketing is a daunting problem, which affects the development of the plant based industry in developing countries like ours. Attitude and the interest of the farmers will play a crucial role in strengthening this field as a new venture.

In spite of the above fact still medicinal plant cultivation is not a very successful venture in commercial farming. The predominant reasons for less favourable attitude towards the adoption of medicinal plants cultivation may be due to lack of technical know-how, lack of awareness about the marketing channels and their utilization and factors such as govt. policy, attitude, availability of quality seed material, water, protection measures, storage facilities and construction of cold storage particular for medicinal plants, processing and so on. Considering the significance of constrains it was felt necessary to find out the major barricades which hinder the attitude of the farmers towards the cultivation of medicinal plants particulate Ajwain crop selected in the study area. Therefore present study was undertaken with the objective: To study the constrains perceived by the farmers towards the cultivation of Ajwain crop.

\section{Materials and Methods}

The present study was conducted in Nimbahera and Chhoti Sadri panchayatsamities of Chittorgarh District, Rajasthan. From these panchayatsamities, four each villages were selected from both panchayatsamities where most of the famers were involved in the cultivation of Ajwain crop and having favourable attitude towards the medicinal plants. The number of famers with Ajwain cultivation was decided for villages by proportionate sampling method. The famers of each village were selected by Simple Random Techniques. In this way five each farmers were selected from each village. Thus, the total study sample consisted of 80respondents from all the 8 selected villages of Nimbahera and Chhotisadri panchayatsamities of Chittorgarh district (Table 1). The data were collected from each respondent through personal interview method with the help of structured schedule. The constraints as perceived by respondents were scored on the basis of magnitude of the problem as per Meena and Sisodia (2004). The respondents were recorded and converted into mean percent score and constraints were ranked accordingly as per Warde et al., (1991).

\section{Results and Discussion}

In the present investigation an attempt had been made to categories the major constraints into suitable topics viz. technical, marketing, financial and storage constraints faced by the Ajwain growers. Lack of technical backstopping about cultivation of medicinal crops was the most important constraints perceived by Ajwain growers with mean per cent score 68.33 respectively was ranked first by respondents. This may be due to the unawareness of farmers about availability of technical know-how of scientific cultivation practices. The next imperative constraints perceived by the respondents while growing Ajwain crop was "Lack of training programme on cultivation of medicinal crop" with 66.25 MPS and ranked second. This was followed by the constraints "Poor knowledge about critical stages of medicinal cultivation" 
which was also singled out as one of the important technological constraints by the farmers cultivating the Ajwain crop with 62.50 MPS and ranked third respectively. Further analysis of table clearly indicates that "Lack of technology suitable for resource poor farmers of the study area", "Untimely technical advice to the farmers" and "medicinal crops are not included in the TOT programme of state department of agriculture" were also felt to be important constraints by both the category of Ajwain growers. Table 2 clearly shows that majority of marginal and small Ajwain growers were confronted with the "Insufficient system to deliver the technical input at the door steps" with 60.41 MPS and ranked seventh by the Ajwain farmers respectively. While, close look of the table 2 indicates the constraints which was given least importance by the Ajwain growers was "Complex cultivation practices" with 57.12 per cent respectively in the hierarchy of the technological constraints. Similar results are in line with the Meena (2006) and it was supported by the findings of Kanbid and Sharma (1994).

An observation of Table 2 indicates that "Lack of regular market increase the malpractices of middleman" was expressed as the most important constraint by the Ajwain growers with mean per cent score 65.64 per cent respectively and was ranked first by the respondents. The realization of that problem might be due to the fact that still the farmers have not much knowledge and awareness about the regulated markets or mandies where they can sell their produce on better price. Usually they prefer to sell their produce directly to the middleman (bepari and hawker/ canvasor). Usually the middleman come to them and the cultivators do not have to face the hassle of transportation or selling those in the open market. This was followed by the constraints of "Distant location of markets" and Distress sale due to immediate need of money" faced by Ajwain grower with MPS of 63.74 and 63.00 and was placed second and third ranked by the Ajwain respondents respectively.

This was followed by the "Support price is not remunerative" "High transport charges" "Unreliable market channels" the extent of these constraints perceived by the farmers was 62.41, 62.00 and 61.50 MPS with fourth, fifth and sixth respectively.

Table.1 Village-wise selected respondents

\begin{tabular}{|c|c|c|c|c|c|}
\hline \multirow[t]{2}{*}{ District } & \multirow{2}{*}{$\begin{array}{c}\text { Panchayat } \\
\text { Samities }\end{array}$} & \multirow[t]{2}{*}{ Village } & \multicolumn{3}{|c|}{ Selected respondents } \\
\hline & & & Small & Marginal & Total \\
\hline \multirow[t]{8}{*}{ A. Chittorgarh } & \multirow[t]{4}{*}{ 1) Nimbahera } & a) Godula & 5 & 5 & 10 \\
\hline & & b) Charliya & 5 & 5 & 10 \\
\hline & & c) Mangrol & 5 & 5 & 10 \\
\hline & & d) Keli & 5 & 5 & 10 \\
\hline & \multirow[t]{4}{*}{ 2) Chotti Sadri } & a) Laxmipura & 5 & 5 & 10 \\
\hline & & b) Parsoli & 5 & 5 & 10 \\
\hline & & c) Jaisinghpura & 5 & 5 & 10 \\
\hline & & d) Bohera & 5 & 5 & 10 \\
\hline 1 & 2 & 8 & 40 & 40 & 80 \\
\hline
\end{tabular}

Survey, 2007-2008 
Table. 2 Constraints perceived by the respondents in cultivation of Ajwain crop

\begin{tabular}{|c|c|c|c|}
\hline S.No & Particulars & MPS & Rank \\
\hline A) & Technological constraints & & \\
\hline 1 & Complex cultivation practices & 57.12 & 10 \\
\hline 2 & Medicinal plants not included in the TOT programme of state department of agriculture & 62.99 & 5 \\
\hline 3 & Lack of technology suitable for resource poor farmers of the study area & 63.74 & 4 \\
\hline 4 & Untimely technical advice to the farmers & 61.50 & 6 \\
\hline 5 & Lack of technical backstopping about cultivation of medicinal crop & 68.33 & 1 \\
\hline 6 & Lack of technical guidance in PHT of medicinal crops & 60.00 & 8 \\
\hline 7 & Poor knowledge about critical stages of medicinal plant cultivation & 65.00 & 3 \\
\hline 8 & Lack of training programme on cultivation of medicinal crops & 66.25 & 2 \\
\hline 9 & Insufficient literature on medicinal plant cultivation in local languages & 59.00 & 9 \\
\hline 10 & Insufficient system to deliver the technical input at the door steps & 60.41 & 7 \\
\hline B) & Marketing Constraints & & \\
\hline 11 & High transport charges & 62.00 & 5 \\
\hline 12 & Lack of regular market increase the malpractices of middleman & 65.46 & 1 \\
\hline 13 & Distress sale due to immediate need of money & 63.33 & 3 \\
\hline 14 & Unreliable market channels & 61.50 & 6 \\
\hline 15 & Support price is not remunerative & 62.41 & 4 \\
\hline 16 & Distant location of markets & 63.74 & 2 \\
\hline 17 & Lack of group marketing & 58.74 & 8 \\
\hline 18 & Poor co-operative marketing systems & 60.00 & 7 \\
\hline 19 & Low purchasing power of consumer & 57.87 & 9 \\
\hline C) & Storage Constraints & & \\
\hline 20 & Grading problem in medicinal crop & 64.50 & 4 \\
\hline 21 & Very high rent on storage of medicinal crops & 66.33 & 3 \\
\hline 22 & Lack of proper storage facilities for medicinal crops & 71.00 & 1 \\
\hline 23 & Perishable nature of commodity & 58.50 & 8 \\
\hline 24 & Storage of medicinal plant produce is a highly technical job & 59.90 & 7 \\
\hline 25 & Lack of knowledge about insect-pest and disease control measures during storage & 63.16 & 6 \\
\hline 26 & No preservation industry in nearby area & 63.50 & 5 \\
\hline 27 & Construction of cold storage house is capital intensive task & 68.57 & 2 \\
\hline D) & Financial Constraints & & \\
\hline 28 & High cost of planting material & 66.25 & 2 \\
\hline 29 & Lack of credit facilities & 67.50 & 1 \\
\hline 30 & Lack of provision of subsidy & 61.25 & 7 \\
\hline 31 & High cost of cultivation & 62.00 & 5 \\
\hline 32 & High labour cost & 61.65 & 6 \\
\hline 33 & High interest on repayment of credits & 60.75 & 8 \\
\hline 34 & Unawareness about credit providing agencies & 62.41 & 4 \\
\hline 35 & High transportation cost & 64.40 & 3 \\
\hline 36 & Uncertainty and Risk & 56.16 & 9 \\
\hline
\end{tabular}

\begin{tabular}{|l|l|l|l|}
\hline S.No & Particularly & MPS & Rank \\
\hline 1 & Technology constraints & 69.05 & I \\
\hline 2 & Marketing constraints & 61.50 & II \\
\hline 3 & Financial constraints & 60.65 & III \\
\hline 4 & Storage constraints & 58.34 & IV \\
\hline
\end{tabular}

MPS: Mean Per cent Score

The constraint perceived by the majority of both the Ajwain growers and placed in the bottom of the list was "Poor co-operative marketing system", "Lack of group marketing", and Low purchasing power of consumer" respectively. The MPS of these constraints were $60.00,58.74$ and 57.87 respectively. The present findings are also supported by Singh (2010) who observed that poor co-operative marketing system and distress sale due to immediate need of money were the important problem faced by the mango growers. Brar (2008) revealed that lack of regularize market, high transportation 
and distant locations of markets were the important constraints perceived by the mandarian growers.

An observation of Table 2 indicates that "Lack of proper storage facilities for medicinal crops" was expressed as major constraint with very high intensity by the cultivator of Ajwain crop with 71.00 MPS and ranked first respectively. The next important constraint faced by Ajwain growers was "Construction of cold storage house is capital intensive task" with 68.57 MPS and ranked second by Ajwain growers respectively. The cost required in construction of storage house was very high, so the farmers could not afford to build it their own level, due to this reason farmers were preferred to put their produces into private and nearby cold storage houses.

This was followed by "very high rent on storage of medicinal crops", "Grading problem in medicinal crop", "No preservation industry in nearby area", and "Lack of knowledge about inspect-pest and disease control measures during storage" the extent of these constraints perceived by the marginal respondents of Ajwain growers was 66.33, 64.50, 63.50 and 63.16 MPS and ranked third, fourth, fifth and sixth respectively.

It was revealed that "Storage of medicinal plant produce is a highly technical job" and "Perishable nature of commodity" were perceived as least important constraints by Ajwain growers with MPS 59.90 and 58.50 respectively. The present findings are in line with the Yadav (2006) who observed that lack of storage facilities were most important constraint perceived by the Mandarian growers.

The data incorporated in table 2 revealed that "Lack of credit facilities" was expressed as the most important constraint perceived by the respondents of Ajwain growers with 69.16 and 65.83 MPS respectively and ranked first. This was followed by "high cost of planting material" with MPS 66.25 and placed second ranked by the Ajwain growers. The next important constraint perceived by the Ajwain grower was "High transportation cost" with 64.40 MPS and placed third ranked respectively. This was followed by "Unawareness about credit providing agencies", "High cost of cultivation", High labour cost" with MPS of 62.41, 62.00 and 61.65 and placed fourth fifth and sixth ranked respectively. It was further observed that constraints perceived at lowest by Ajwain growers was "Uncertainty and Risk" with the extent of 56.16 MPS respectively. It was line with the Dhanasekaran (1990) reported that unawareness about the funding agencies, lacks of subsidies were found major constraints by respondents for growing trees.

\section{Category-wise constraints as perceived}

In order to find out the relationship between the ranks accorded by groups of respondents to different category of constraints, rank order correlation was calculated (Table 2). It is clear that the major category of constraint i.e. Technology constraint $(69.05 \%)$ was the top ranked as perceived by the farmers involved in the cultivation of Ajwain crop. Other major category of constraints as perceived by the farmers in cultivation of Ajwain crop like marketing constraints $(61.50 \%)$ and financial constraints (60.65\%) were accorded II and III ranks in rank order by the respondents. Whereas, the storage constraints $(58.34 \%)$ were perceived least important and placed IV rank in the hierarchy of list.

It was observed that technology constraint was most important constraint as it was ranked in 1st position. This was followed by marketing constraints, financial constraints and storage constraints which were accorded 
II, III and IV ranks in rank order by the respondents. While analyzing overall constraints as perceived by the farmers, it was found that Lack of technical backstopping about cultivation of medicinal crop, Lack of training programme on cultivation of medicinal crops, Lack of regular market increase the malpractices of middleman, Distress sale due to immediate need of money, Lack of proper storage facilities for medicinal crops, Construction of cold storage house is capital intensive task, Lack of credit facilities, High cost of planting material and Unawareness about credit providing agencies were the major constraints causing serious concern to the Ajwain growers in Chittorgarh district of Rajasthan.

\section{References}

Brar, K.S. 2008. An analytical study on knowledge, persuasion and adoption of farmers about recommended practices of kinnow cultivation (Citrus delicious) in Rajasthan. Ph.D. Thesis, Maharana Pratap University of Agriculture and Technology, Udaipur.

Dhanasekaran, D. 1990. Social Forestry performance and issue. Economic Affairs 35:32-40.

Kanbid, B.R. and Sharma, D.D. (1994).
Adoption constraints of scientific horticultural technology. Indian Journal of Extension Education. XXX (1\&2): 119-122.

Meena, S. R. and Sisodia, S. S. (2004). Constraints as perceived by the respondents in adoption of recommended guava production technology. Rajasthan Journal of Extension Education. (12-13) :146-153.

Singh, K. 2010. Problem and Prospects of Mango Cultivation in Tribal Districts of Southern (Rajasathan). Ph.D. thesis submitted to Maharana Pratap University of Agriculture and Technology, Udaipur

Wrade, P.N., Bhople, R.S. and Choudhary, D.P. (1991). Adoption of dry land horticulture technology. Maharashtra Journal of Extension Education. X (2): 108.

Yadav, B. 2006. A study on knowledge and adoption of improved production technology of mandarian by the farmers in Jhalrapatan PanchayatSamiti in Jhalawar district of Rajasthan. M.Sc. (Ag.) thesis submitted to Rajasthan Agriculture University Bikaner, Rajasthan.

\section{How to cite this article:}

Kanwat, M., N.R. Meena and Meena, N.K. 2017. Factors Influencing in Ajwain Cultivation in Chittorgarh District of Rajasthan, India. Int.J.Curr.Microbiol.App.Sci. 6(12): 3817-3822. doi: https://doi.org/10.20546/ijcmas.2017.612.439 